\title{
Broilerien hyvinvoinnin mittaaminen tilalla
}

\author{
Petra Tuunainen ${ }^{1)}$, Anna-Kaisa Myllykoski ${ }^{2)}$ \\ ${ }^{1)}$ Maa- ja elintarviketalouden tutkimuskeskus MTT, Animale, 31600 Jokioinen, etuni- \\ mi.sukunimi@mtt.fi \\ ${ }^{2)}$ Helsingin yliopisto, Maataloustieteen laitos, Koetilantie 5, 00014 Helsingin yliopisto, etuni- \\ mi.sukunimi@helsinki.fi
}

\section{TIIVISTELMÄ}

Tuotantoeläinten hyvinvointia on perinteisesti määritelty mittaamalla tuotantoa, mutta nykyään hyvinvoinnin mittaamisessa keskitytään tiloilla elävästä eläimestä tehtyjen havaintojen tekemiseen. Tämän tutkimuksen tarkoituksena oli arvioida Welfare Quality ${ }^{\circledR}$ - mittausjärjestelmän tilalla tehtävien mittausmenetelmien soveltuvuutta suomalaiseen tuotantoon ja saada tietoa broileriparvien hyvinvoinnista.

Tilakäynneillä arvioitiin yhteensä 45 broileriparvea koko Suomen alueelta 1.1-28.3.2013 välisenä aikana. Arvioinnit tehtiin teurastusta edeltävällä viikolla broilereiden ollessa 23-35 vrk:n ikäisiä. Mittauksien tulokset yhdistettiin teurastamoilta saatuihin parven teurastustietoihin ja tästä aineistosta pyrittiin löytämään mahdollisia yhdysvaikutuksia terveyden, hyvinvoinnin, kasvatuksen ja teurastuksen välillä.

Welfare Quality- mittausjärjestelmä soveltui osittain myös suomalaiseen tuotantoon. Tilakäynnit onnistuivat suunnitelmien mukaisesti ja lintujen hyvinvoinnin taso tiloilla oli normaali. Tilakäynneillä työläimpiä menetelmiä olivat kävelytesti ja lintujen kiinniottamista ja nostelua vaatineet puhtauden, jalkapohjien ja kintereiden arvioinnit. Käyttäytymistestiä ja pölyn mittausmenetelmää muokkaamalla, niiden luotettavuus ja käyttökelpoisuus paranevat. Käyttäytymistestissä käytettävät adjektiivit tulisi valita paremmin linnun käyttäytymistä kuvaileviksi ja pölyn mittaus pitäisi suorittaa useammin ja eri paikoista. Ainoastaan sopivan lämpötilan määrittämisessä käytettävä testin ja lähestymistestin arvioitiin olevan epäluotettavia ja tarkoitukseen hieman sopimattomia. Tutkimuksessa havaittiin, että jo pelkästään pehkun laatua ja lintujen kinnerten kuntoa arvioimalla saadaan luotettavaa tietoa parven hyvinvoinnista. Pehkun laatu vaikutti tilastollisesti merkitsevästi lintujen puhtauteen, jalkapohjien ja kinnernivelten kuntoon $(\mathrm{P}<0,005)$. Kostealla pehkulla linnut elopainoltaan suuret ja huonommin liikkuvat linnut makasivat enemmän ja linnut olivat likaisempia ja jalkapohja- sekä kinnerniveltentulehduksia oli enemmän. Kinnertulehdusten määrän huomattiin lisäksi korreloivan tilastollisesti merkitsevästi lintujen kävelyn ja puhtauden kanssa $(\mathrm{P}<0,005)$, niin että linnut, joilla oli kinnertulehduksia, olivat likaisempia ja liikkuivat huonommin. Lisäksi lievien jalkapohjatulehdusten määrä nousi linnuilla, joilla oli myös lieviä kinnertulehduksia $(\mathrm{P}<0,0001)$. Teurastamolla määritettyjen jalkapohjapisteiden tulokset huomattiin myös olevan suoraan verrannollisia tilakäynneillä tehtyjen jalkapohjaarviointien kanssa $(\mathrm{P}<0,0001)$, joten jalkapohjien tarkkailu on tehokkainta tehdä teurastamolla.

Mittausten ongelmana oli ainoastaan se, että kasvattajalla on vain rajalliset mahdollisuudet vaikuttaa hyvinvointiin mittauksen jälkeen, koska mittaukset tehdään niin lähellä teurastusta. Kuitenkin jo pelkästään pehkun laatua seuraamalla voidaan lintujen terveyttä ja hyvinvointia seurata koko kasvatusaikana melko kattavasti.

Asiasanat: broileri, hyvinvoinnin mittaaminen, Welfare Quality 


\section{JOHDANTO}

Tuotantoeläinten hyvinvointia on perinteisesti määritelty mittaamalla tuotantoa, sillä on ajateltu että huonosti voiva eläin ei tuota hyvin. Nykyään on kuitenkin kehitetty erilaisia eläinperusteisia hyvinvoinnin mittausmenetelmiä, yhtenä niistä Welfare Quality®, jota kehittämässä oli useita yliopistoja ja tutkimuslaitoksia Euroopassa. Welfare Quality ${ }^{\circledR}$ perustuu erilaisten hyvinvointia kuvaavien muuttujien yhdistämiseen.

Welfare Quality® koostuu neljästä pääluokasta: Hyvä ruokinta, hyvät olosuhteet, hyvä terveys ja tarkoituksen mukainen käyttäytyminen (kuva 1). Jokainen näistä pääluokista koostuu eri muuttujista, joita arvioidaan joko tilalla tai teurastamolla. Näissä arvioinneissa keskityttiin tilalla mitattaviin muuttujiin, joiden avulla pyrittiin selvittämään lintujen makuualustan mukavuutta (lintujen puhtaus, pölyn määrä ja pehkun laatu), sopivaa lämpötilaa (läähätys ja yhteen painautuminen), esteetöntä liikkumista (kasvatustiheys), lintujen kuntoa ja sairauksia (kuolleisuus, karsinta, ontuminen, jalkapohjatulehdukset ja kinnervauriot) sekä lintujen tunnetilaa (Qualitative Behaviour Assessment, QBA ja lähestymistesti).

Tilakäyntien tarkoituksena oli arvioida Welfare Quality®- mittausjärjestelmän soveltuvuutta suomalaiseen tuotantoon ja saada tietoa parvien tilanteesta. Mittauksien tulokset yhdistettiin teurastamoilta saatuihin saman parven teurastustietoihin ja tästä aineistosta pyrittiin löytämään mahdollisia yhdysvaikutuksia terveyden, hyvinvoinnin, kasvatuksen ja teurastuksen välillä. Tarkoituksena oli saada mahdollisuus kehittää suomalaiseen tuotantoon sopiva hyvinvoinnin mittausjärjestelmä soveltamalla Welfare Quality ${ }^{\circledR}$ - arviointia tiloilla.

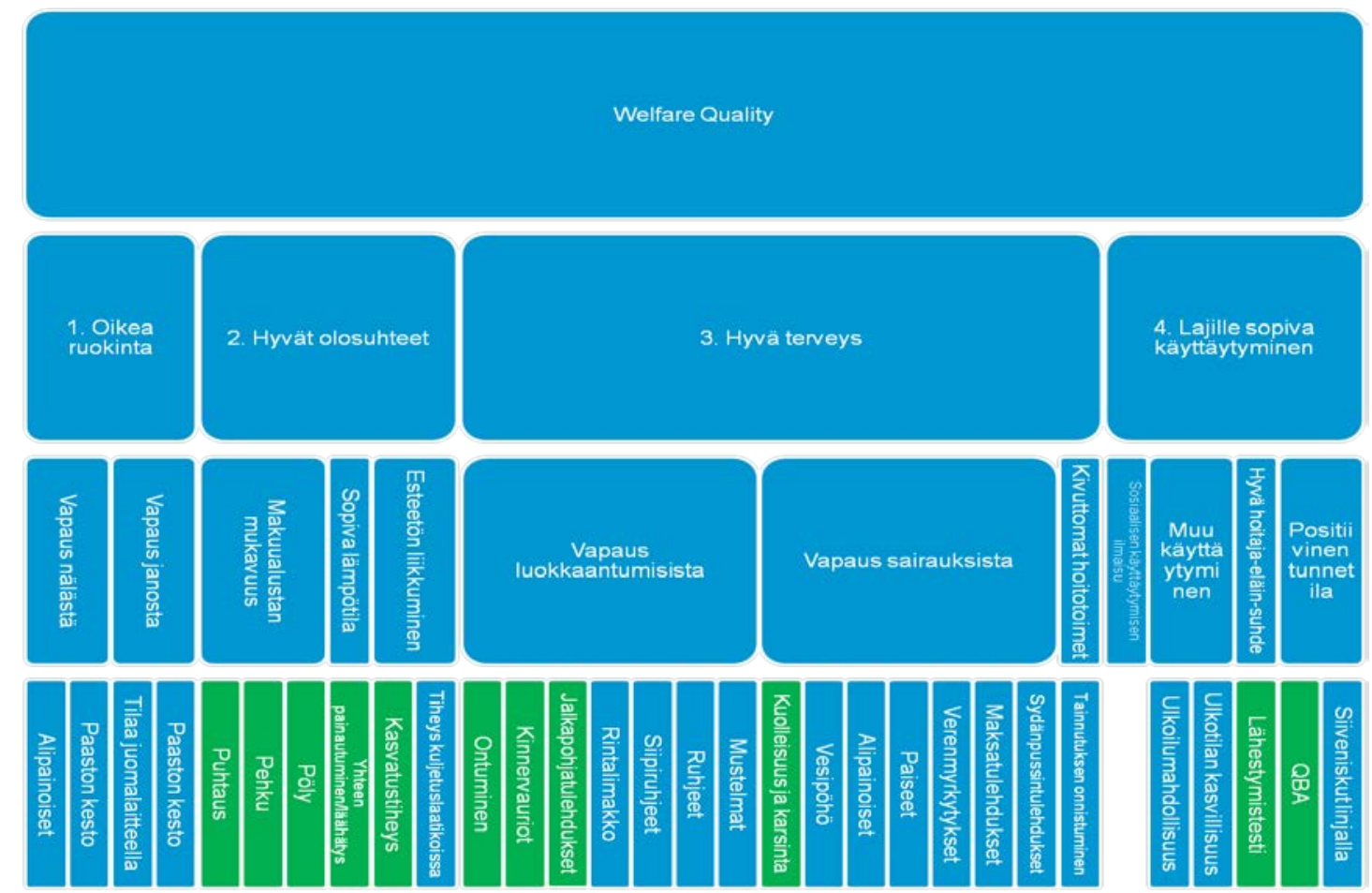

Kuva 1. Welfare Qualityn ${ }^{\circledR}$ määrittelemät hyvinvoinnin periaatteet ja kriteerit sekä tilakäynneillä käytettyjen arvioitavien muuttujien listaus (vihreällä)

\section{AINEISTOT JA MENETELMÄT}

Tutkimuksessa arvioitiin yhteensä 45 broileriparvea koko Suomen alueelta. Yhdellä parvella tarkoitetaan tässä tutkimuksessa erillisessä hallissa olevaa linturyhmää. Yhden päivän aikana arvioitiin kaksi parvea samalta tilalta. Yleensä arvioitavana oli parihalli, jossa oli kaksi erillistä parvea. Arvioitavat linnut olivat 23-35 vrk:n ikäisiä (keskimäärin 32 vrk) ja 1,400-2,403 kg painoisia (keskimäärin 1,875 kg). Arvioitavissa parvissa oli arviointipäivänä 6046-33068 kpl broilereita (keskimäärin 17584). Tila- 
käynnit tehtiin 1.1-28.3.2013 aikana. Tilakäyntiin varattiin aikaa 2,5 h/parvi. Yhden päivän aikana arvioitiin yleensä kaksi parvea samalta tilalta.

\section{Taustatiedot}

Mitatuista parvista kerättiin myös taustatietoja tuottajalta ja teurastamolta parven teurastuksen jälkeen. Tarkoituksena oli koota mahdollisimman paljon tietoja linnuista, jotta tilakäynneillä saatuja tuloksia voitiin verrata taustatietoihin ja etsiä toisiaan selittäviä muuttujia. Tiloilta arviointipäivänä kerätyt ja teurastamoilta parven teurastuksen jälkeen saadut taustatiedot on esitetty taulukossa 2. Taulukossa on jokaiselle muuttujalle laskettu keskiarvo, minimi, maksimi ja keskihajonta.

\section{Olosuhteiden arviointi}

Kasvatusosaston ilmanlaatua arvioitiin mittaamalla pölyisyyttä. Ensimmäisenä halliin mentäessä, asetettiin pölyn määrän mittaamista varten musta pahvi lintujen pään yläpuolelle lähelle hallin ovea. Mikäli sopivaa tasoa ei ollut lintujen pään korkeudella (kuten tikkaat), pahvi jätettiin rehuruokkijan päälle. Pahvin annettiin olla paikallaan koko arviointiajan ja pölyn määrä arvioitiin viimeiseksi. Paperille laskeutuneen pölyn määrä arvioitiin 0 (ei pölyä)-4 (paperin väri ei erotu pölyn alta).

Pehkun kunto määritettiin hallissa kuudesta paikasta, hallin nurkissa nippa- ja ruokintalinjojen välistä ja keskellä tehtiin yksi arvio nippalinjan alta ja toinen ruokintalinjan alta. Hallin saama arvio on keskiarvo näistä mittauksista. Pehkun kunto arvioitiin asteikolla 0 (kokonaan kuiva ja mureneva)- 4 (pehkussa on kuiva kuori, mutta kuoren murruttua pehku on märkää ja astuttaessa jää kengänjälki).

Kasvatusosaston lämpötilan sopivuutta linnuille arvioitiin tarkkailemalla lintuja viidellä arviointialueella. Jokaisella alueella arvioitiin silmämääräisesti kuinka suuri osa linnuista läähättää (indikaattorina liian korkealle lämpötilalle) ja kuinka suuri osa linnuista on painautuneena toisiinsa (indikaattorina kylmyydestä). Koko kasvatusosaston lämpötilan sopivuus muodostui viiden alueen keskiarvosta.

\section{Lintujen käyttäytymisen arviointi}

Lähestymistestillä (Avoid distance test, ADT) pyrittiin arvioimaan lintujen luottavaisuutta ihmisiä kohtaan. Arvioija lähestyi lintuja rauhallisesti ja kyykistyi lintujen tasolle. Arvioija ojensi käden ja laski niiden lintujen määrän, jotka olivat kosketusetäisyydellä yrittäen samalla koskettaa näitä lintuja. Lintujen kokonaislukumäärä kosketusetäisyydellä ja kosketettujen lintujen osuus tästä kirjattiin ylös. Lähestymistesti toistettiin yhteensä 21 kertaa arvioinnin aikana.

Lintujen käyttäytymistä tarkasteltiin keskellä kasvatusosastoa käyttäytymistestillä (Qualitative behaviour assessment, QBA) avulla. Käyttäytymistestissä kuvaillaan eläimien käyttäytymistä ennalta sovittuja adjektiiveja käyttäen. Adjektiivit kuvailevat positiivista tunnetilaa (aktiivinen, rento, mukava, luottavainen, rauhallinen, tyytyväinen, utelias, energinen, ystävällinen, touhukas, leikkisä) ja negatiivista tunnetilaa (jännittynyt, masentunut, epävarma, turhautunut, kyllästynyt, pelästynyt, unelias, hermostunut, ahdistunut, avuton, pelokas, kiihtynyt). Käyttäytymistesti tehdään niin, että arvioija asettuu rauhallisesti katselemaan lintuja. Arvioija tarkkailee lintuja useita minuutteja. Sitten arvioija arvioi lintujen käyttäytymistä käyttämällä 20 ennalta annettua adjektiivia. Jokaista adjektiivia kuvaa arvioinnissa jana, jolla on minimi 0 ja maksimi 12 . Arvioija laittaa janalle pisteen siihen kohtaan, mikä hänen mielestään vastasi lintujen käyttäytymistä. Minimi tarkoittaa, ettei käyttäytymistä havaittu olenkaan ja maksimi sitä että käyttäytyminen oli tarkkailtavassa ryhmässä voimakasta ja hallitsevaa. Käyttäytymistestin tulokset ovat täysin riippuvaisia arvioijasta.

\section{Lintujen kävelykyvyn, puhtauden, jalkapohjien ja kintereiden arviointi}


Koko parven lintujen puhtauden, jalkapohjien ja kintereiden kunnon sekä kävelykyvyn arvioimista varten pyrittiin tekemään edustava otanta linnuista viidellä alueella kasvatusosastoa. Puhtauden sekä jalkapohjien ja kintereiden kunnon arvioimiseen haluttiin kaikkiaan vähintään 100 lintua ja kävelytestiin vähintään 150 lintua. Yhdellä arviointialueella rajattiin kerralla noin 30 linnun ryhmä. Tutkittava linturyhmä saarrettiin rauhallisesti aitaverkon avulla erikseen muista linnuista, jolloin vältyttiin samojen lintujen toistuva käsittely. Mikäli aitaukseen saarrettiin enemmän kuin 30 lintua, kaikki aitauksessa olleet linnut arvioitiin.

Puhtautta arvioitiin neliportaisella asteikolla täysin puhtaasta (0)- täysin likaiseen (3). Puhtaus määritettiin höyhenpeitteeseen ja iholle tarttuneen lian määrän mukaan käyttämällä Welfare Quality $^{\circledR}$-arviointimenetelmän ohjeistusta. Samoilta linnuilta arvioitiin myös jalkapohjien ja kintereiden kunto asteikolla 0 (ei tulehdusta-4 selkeä, laajalle levinnyt tulehdus).

Kävelyä arvioitiin viisiportaisella asteikolla 0 (kävelee sulavasti, nostaa jalkojaan ylös ja jalkapohja taipuu sisäänpäin jalan noustessa, kävely vaikuttaa tasapainoiselta)- 5 (ei pysty kävelemään omin avuin).

Aineistosta etsittiin muuttujaryhmien välisiä korrelaatioita (SAS 9.3), jotta mahdollisesti toisiaan selittävät muuttujat pystyttäisiin löytämään. Analysointia varten aineisto jaettiin seuraavasti:

- $\quad$ Riippumattomat muuttujat (X): ympäristöperäiset muuttujat; hallin rakennusvuosi, hallin pinta-ala, lintujen ikä, kasvatustiheys, hallin sisälämpötila, ulkolämpötila, lintujen elopaino arviointipäivänä, valon määrä, emoparven keski-ikä, juomanippojen määrä, pehkun laatu ja pölyn määrä

- $\quad$ Riippuvat muuttujat (Y): eläinperäiset muuttujat; kävelytestin tulokset, jalkapohjien ja kintereiden kunto, lintujen puhtaus, läähättävien määrä ja lähestymistesti

\section{TULOKSET JA TULOSTEN TARKASTELU}

Hallin olosuhteista tilakäynneillä mitattiin pehkun kuntoa, sopivaa lämpötilaa ja pölyn määrään. Tulokset on esitetty taulukossa 1.

Taulukko 1. Tilakäynneillä määritettyjen mittauksien keskimääräiset tulokset kaikista mitatuista parvista.

\begin{tabular}{lccccc}
\hline & $\mathrm{lkm}$ & $\mathrm{ka}$ & $\mathrm{std}$ & $\min$ & $\max$ \\
\hline Läähätys, \% linnuista (arvioitu silmämääräisesti parvesta) & 45 & 3,98 & 7,614 & 0,00 & 36,00 \\
Pehkun laatu (0=kuiva ja mureneva-4=tarttuu kenkään) & 45 & 0,66 & 0,584 & 0,00 & 2,00 \\
Pölyn määrä (0=ei pölyä-4=paperin väri ei erotu) & 45 & 0,91 & 0,763 & 0,00 & 3,00 \\
Lähestymistesti, \% linnuista käden ulottuvilla kosketettu & 45 & 74,15 & 18,801 & 33,33 & 96,05 \\
\hline
\end{tabular}

Arvioiduissa halleissa oli keskimäärin kuivat ja hyvät pehkut, vaikka arvioinnit tehtiinkin talvella pahimpien pakkasten aikaan. Ainoastaan nippalinjan alta saimme huonompia tuloksia. Pehkun laadun määrittäminen on yksinkertainen menetelmä tehdä ja kertoo paljon hallin olosuhteista. Pehkun laatua voidaan parantaa kiinnittämällä huomiota esimerkiksi vuotaviin nippoihin ja ilmastoinnin ja lämmityksen tehokkuuteen.

Sopiva lämpötila arvioitiin laskemalla läähättävien tai yhteen painautuneiden lintujen määrää. Keskimäärin parvissa havaittiin läähättäviä lintuja vain alle $5 \%$, mikä on todella vähän. Tämä mittausmenetelmä on subjektiivinen eikä kovin luotettava mittausmenetelmä. Enemmän eroja läähättävien lintujen määrässä nähtiin eri mittauspisteiden välillä kuin eri parvien. Tämä mittausmenetelmä voi sopia paremmin vaihtoehtoista tuotantoa arvioitaessa, koska hallissa, jossa on esim. ulkoilumahdollisuus, voivat olosuhteet olla eri halleissa ja mittauspisteissä erota enemmän tai jos mittaukset olisi tehty kesähelteillä.

Pölyn mittaaminen paperin avulla on hyvin yksinkertainen mittausmenetelmä, ainoastaan paperin paikka on valittava hyvin. Tällä kertaa paperia pidettiin yleisimmin rehulinjan kaukalon päällä, mikä on hallin pölyisin paikka, jos rehulinja on käynnissä. Tällä on todella suuri vaikutus tuloksiin. 
Lisäksi jos pölyn määrä mitattiin vain yhdestä paikasta, niin se kertoo vain sen hetkisen tilanteen sillä paikalla. Samassa hallissa saattaa olla eripuolilla erilaiset olosuhteet eikä tämä mittausmenetelmä ota sitä huomioon. Harhaa tuloksiin saattaa aiheuttaa myös se, että paperi laitettiin paikoilleen ennen mittausta. Paperi keräsi pölyä sen aikaa kun arvioijat olivat hallissa. Kun arvioijat olivat hallissa, linnut liikkuivat normaalia enemmän ja pölyä oli ilmassa enemmän kuin silloin kun linnut ovat rauhallisia. Kuitenkin hyvin pölyisiä halleja ei tilakäynneillä havaittu.

Kävelytestin tulokset luokittain ovat kuvassa 2. Yhteensä tilakäynneillä kävelytesti tehtiin 6843 linnulle, 0,92 \% kaikista arvioiduissa parvissa olleista linnuista. 50, 4 \% arvioiduista linnuista sai kävelystä arvosanan 3, 39,8 \% arvosanan 2, 8,2 \% arvosanan 1 ja 1,0 \% arvosanan 0. Arvosanoilla 1-3 arvioidut linnut ovat vielä kykeneviä liikkumaan ruokintalaitteille ja juomanipoille, kävely ei aiheuta linnuille kipua eikä linnuissa näy muita ulkoisia sairauden merkkejä, mitkä vaikuttaisivat vakavasti lintujen terveyteen. Arvosanan 4 tai 5 saavat linnut taas pitäisi pyrkiä karsimaan, koska linnut eivät pääse liikkumaan ollenkaan tai liikkuvat niin huonosti, että siitä on haittaa niiden terveydelle ja selviytymiselle kasvatuksen loppuun asti. Tällaisilta linnuilta löytyy myös usein ontumisen aiheuttavan sairauden merkkejä, kuten niveltulehdusta ja vesipöhöä. Arvioinneissa arvosanan 4 sai $0,5 \%$ ja arvosanan 5 0,1\% arvioiduista linnuista.

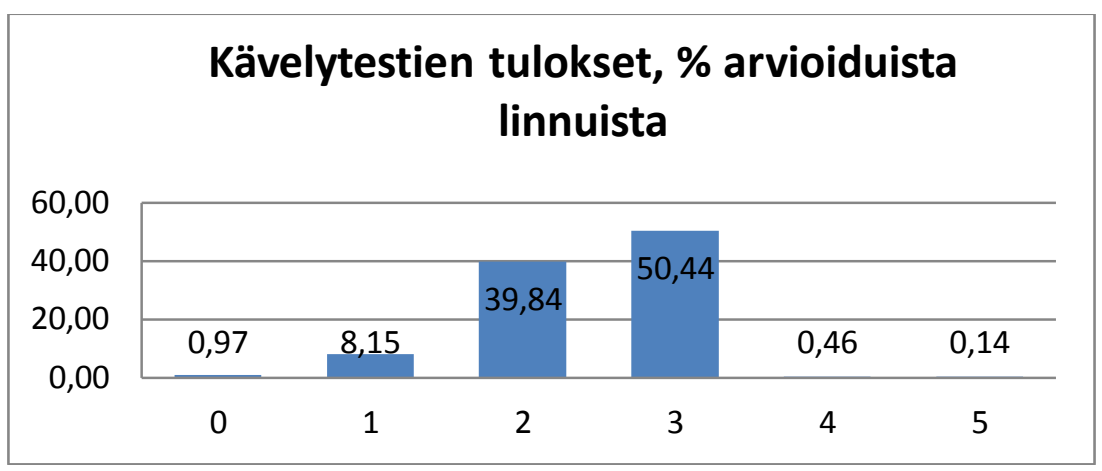

Kuva 2. Kävelytestin tulokset luokittain arvioiduissa parvissa

Puhtaus, jalkapohjat ja kintereet arvioitiin tilakäynneillä yhteensä 6162 linnulta (0,83 \% kaikista arvioiduissa parvissa olevista linnuista). Tulokset on esitetty kuvassa 3. Suurin osa arvioiduista linnuista sai puhtaudesta arvosanan 0 (4,69 \%) tai 1 (93,62 \%), mitä pidetään vielä todella puhtaana. Arvosanan 2 sai vain 1,69 \% linnuista ja arvosanaa 3 ei annettu arviointien aikana yhdellekään linnulle. Jalkapohjille suurin osa linnuista eli 72,31 \% sai arvosanan 0. Arvosanan 1 sai 16,73 \% linnuista, arvosanan 2 10,29 \% ja arvosanan 3 0,68 \% linnuista. Arvosanaa 4 ei annettu yhdellekään arvioiduista linnuista. Kintereet saivat yleisimmin arvosanan 0 (72,29 \%). Arvosanan 1 sai 24,29 \% linnuista, arvosanan 2 3,32 \% ja arvosanan 3 0,1 \% linnuista. Arvosanaa 4 ei annettu yhdellekään arvostellusta linnuista. Siis vakavimpia tulehduksia ei havaittu arvioiduissa linnuissa.

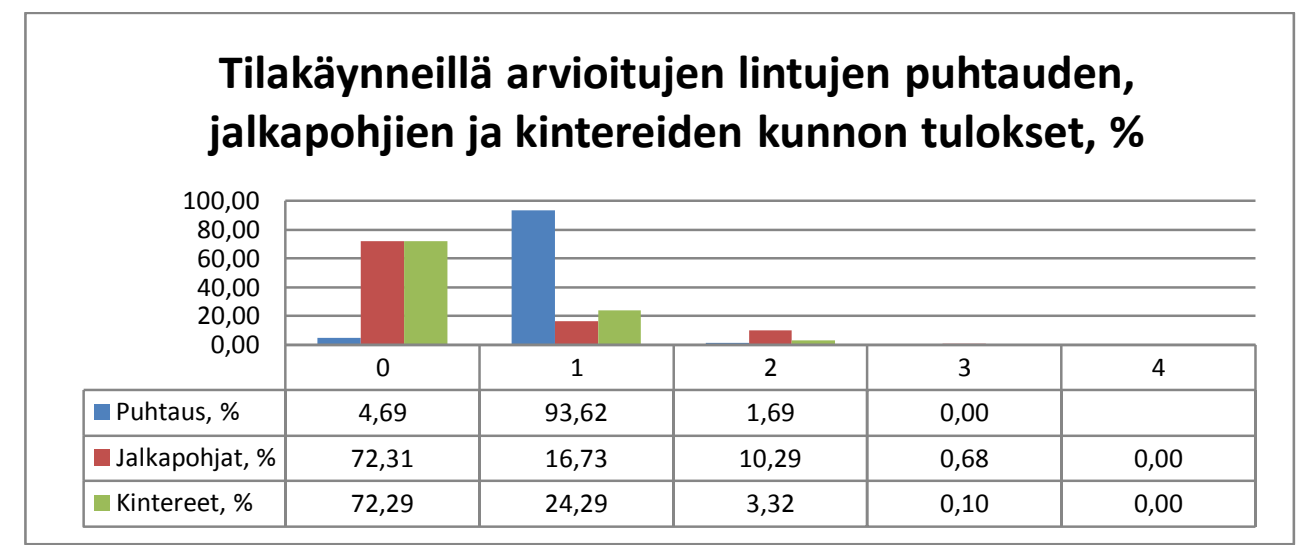

Kuva 3. Puhtauden, jalkapohjien ja kintereiden arvioinnin tulokset 
Käyttäytymistesti on myös täysin subjektiivinen testi. Arvioijan omilla mielipiteillä ja kokemuksella on erittäin suuri vaikutus siihen, mitä adjektiiveja miten, hän arvioinnissa käyttää. Käyttäytymistestillä saatiin kuitenkin jonkin verran eroa parvien välille ja arvioijien kokemus ainakin parani. Käyttäytymistestin huonoina puolina pidettiin valmiiksi annettujen adjektiivien käyttämistä. Valmiissa adjektiiveissa on monia, joita ei osattu käyttää ollenkaan. Esimerkiksi masentunut, unelias ja leikkisä olivat sellaisia joita harvoin käytettiin arvioinnissa. Tällaista menetelmää voisi hieman sovellettuna käyttää kuitenkin. Adjektiivit pitäisi miettiä helpommin lintua kuvaaviksi ja niiden määrää ehkä karsia.

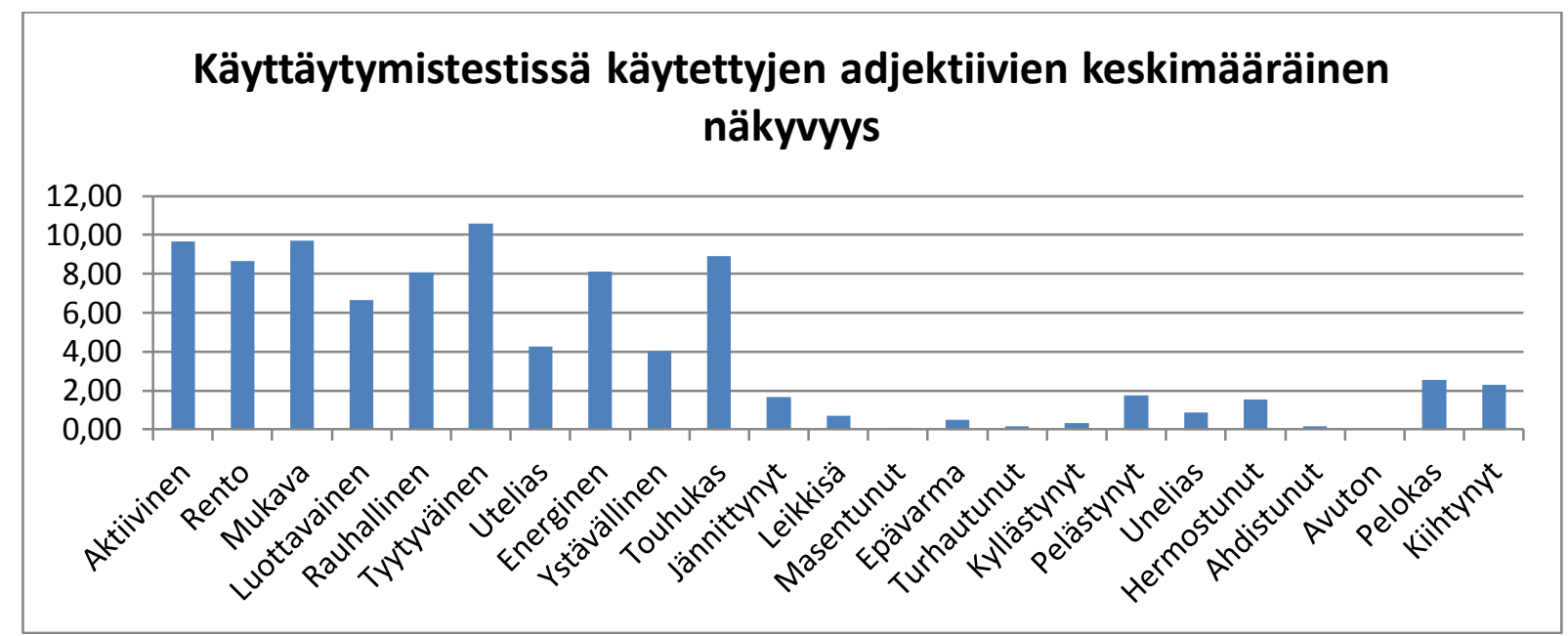

Kuva 4. Käyttäytymistestin keskimääräiset tulokset

Pehkun laatu vaikutti merkitsevästi lintujen puhtauteen, jalkapohjien ja kinnernivelten kuntoon. Kostealla pehkulla linnut huonommin liikkuvat linnut makasivat enemmän ja linnut olivat likaisempia ja jalkapohja- sekä kinnerniveltentulehduksia oli enemmän (taulukko 2). Kuitenkin mielenkiintoisin havainto oli, että kinnerten kunnon ja kävelytestin, jalkapohjien ja puhtauden arviointien tulosten välillä löytyi merkittävät yhdysvaikutukset (taulukko 3).

Kinnertulehdusten määrän huomattiin lisäksi korreloivan tilastollisesti merkitsevästi lintujen kävelyn ja puhtauden kanssa, niin että linnut, joilla oli kinnertulehduksia, olivat likaisempia ja liikkuivat huonommin. Lisäksi lievien jalkapohjatulehdusten määrä nousi linnuilla, joilla oli myös lieviä kinnertulehduksia. Eli jo pelkästään pehkun laatua ja lintujen kinnerten kuntoa arvioimalla saadaan luotettavaa tietoa parven hyvinvoinnista.

Taulukko 2. Pehkun ladun vaikutus lintujen puhtauteen sekä jalkapohjien ja kinnerten kuntoon (Spearmannin korrelaatioiden r-arvot).

\begin{tabular}{|c|c|c|}
\hline & & $\begin{array}{c}\text { Pehkun laatu } \\
\text { r-arvot }\end{array}$ \\
\hline \multirow[t]{2}{*}{ Puhtaus, \% } & luokat $0+1$ & $\begin{array}{c}-0,50423 \\
* *\end{array}$ \\
\hline & luokat $2+3$ & $\begin{array}{c}0,50423 \\
* *\end{array}$ \\
\hline \multirow[t]{3}{*}{ Jalkapohjat, \% } & luokka 0 & $\begin{array}{c}-0,68887 \\
* * *\end{array}$ \\
\hline & luokat $1+2$ & $\begin{array}{c}0,68953 \\
* * *\end{array}$ \\
\hline & luokat 3+4 & $\begin{array}{c}0,4133 \\
* *\end{array}$ \\
\hline \multirow[t]{2}{*}{ Kintereet, \% } & luokat $0+1$ & $\begin{array}{c}-0,42658 \\
* *\end{array}$ \\
\hline & luokat $2+3+4$ & $\begin{array}{c}0,42658 \\
* *\end{array}$ \\
\hline
\end{tabular}

*** $\mathrm{P}<0,0001, * * \mathrm{P}<0,01, * \mathrm{P}<0,05$ ja o $\mathrm{P}<0,10$ 
Taulukko 3. Kintereiden kunnon yhteisvaikutus jalkapohjien, puhtauden ja kävelyn kanssa (Spearmannin korrelaatioiden r-arvot).

\begin{tabular}{|c|c|c|c|c|c|c|c|c|}
\hline & & \multicolumn{3}{|c|}{ Jalkapohjat, \% } & \multicolumn{2}{|c|}{ Puhtaus, \% } & \multicolumn{2}{|c|}{ Kävely, \% } \\
\hline & & luokka 0 & $\begin{array}{c}\text { luokat } \\
1+2\end{array}$ & $\begin{array}{c}\text { luokat } \\
3+4\end{array}$ & $\begin{array}{c}\text { luokat } \\
0+1\end{array}$ & $\begin{array}{c}\text { luokat } \\
2+3\end{array}$ & $\begin{array}{c}\text { luokat } \\
0+1+2+3\end{array}$ & $\begin{array}{c}\text { luokat } \\
4+5\end{array}$ \\
\hline & & & \multicolumn{6}{|c|}{ r- arvot } \\
\hline \multirow[t]{6}{*}{ Kintereet, \% } & luokka 0 & $\begin{array}{c}0,51133 \\
* * *\end{array}$ & $\begin{array}{c}-0,51436 \\
* * *\end{array}$ & $-0,1628$ & $\begin{array}{c}0,46634 \\
* *\end{array}$ & $\begin{array}{c}-0,46634 \\
* *\end{array}$ & $\begin{array}{c}0,27168 \\
0\end{array}$ & $\begin{array}{c}-0,27168 \\
0\end{array}$ \\
\hline & luokka 1 & $\begin{array}{c}-0,50522 \\
* * *\end{array}$ & $\begin{array}{c}0,51049 \\
* * *\end{array}$ & 0,11707 & $\begin{array}{c}-0,41792 \\
* *\end{array}$ & $\begin{array}{c}0,41792 \\
* *\end{array}$ & $-0,18234$ & 0,18234 \\
\hline & luokka 2 & $-0,17565$ & 0,16831 & 0,23034 & $\begin{array}{c}-0,51013 \\
* * *\end{array}$ & $\begin{array}{c}0,51013 \\
* * *\end{array}$ & $\begin{array}{c}-0,42442 \\
* *\end{array}$ & $\begin{array}{c}0,42442 \\
* *\end{array}$ \\
\hline & luokka 3 & $-0,16394$ & 0,16394 & 0,0509 & 0,08448 & $-0,08448$ & $-0,11665$ & 0,11665 \\
\hline & luokat $0+1$ & 0,17805 & $-0,17058$ & $-0,2426$ & $\begin{array}{c}0,49488 \\
* * *\end{array}$ & $\begin{array}{c}-0,49488 \\
* * *\end{array}$ & $\begin{array}{c}0,41693 \\
* *\end{array}$ & $\begin{array}{c}-0,41693 \\
* *\end{array}$ \\
\hline & luokat $2+3+4$ & $-0,17805$ & 0,17058 & 0,2426 & $\begin{array}{c}-0,49488 \\
* * *\end{array}$ & $\begin{array}{c}0,49488 \\
* * *\end{array}$ & $\begin{array}{c}-0,41693 \\
* *\end{array}$ & $\begin{array}{c}0,41693 \\
* *\end{array}$ \\
\hline
\end{tabular}

\section{JOHTOPÄÄTÖKSET}

Welfare Quality- mittausjärjestelmä soveltui osittain myös suomalaiseen tuotantoon. Tilakäynnit onnistuivat suunnitelmien mukaisesti ja lintujen hyvinvoinnin taso tiloilla oli normaali. Tilakäynneillä työläimpiä menetelmiä olivat kävelytesti ja lintujen kiinniottamista ja nostelua vaatineet puhtauden, jalkapohjien ja kintereiden arvioinnit. Käyttäytymistestiä ja pölyn mittausmenetelmää muokkaamalla, niiden luotettavuus ja käyttökelpoisuus paranevat. Käyttäytymistestissä käytettävät adjektiivit tulisi valita paremmin linnun käyttäytymistä kuvaileviksi ja pölyn mittaus pitäisi suorittaa useammin ja eri paikoista. Ainoastaan sopivan lämpötilan määrittämisessä käytettävä testin ja lähestymistestin arvioitiin olevan epäluotettavia ja tarkoitukseen hieman sopimattomia. Mittausten ongelmana oli ainoastaan se, että kasvattajalla on vain rajalliset mahdollisuudet vaikuttaa hyvinvointiin mittauksen jälkeen, koska mittaukset tehdään niin lähellä teurastusta. Kuitenkin jo pelkästään pehkun laatua seuraamalla voidaan lintujen terveyttä ja hyvinvointia seurata koko kasvatusaikana melko kattavasti.

\section{KIRJALLISUUS}

Welfare Quality ${ }^{\circledR}$. 2009. Welfare Quality ${ }^{\circledR}$ assessment protocol for poultry (broilers, laying hens. Welfare Quality ${ }^{\circledR}$ Consortium, Lelystad, Netherlands. 114 s. 